\title{
New and interesting clavarioid fungi from the hemiboreal zone of Finland
}

\author{
ANTON SHIRYAEV
}

\begin{abstract}
SHIRYAEV, A. 2008: New and interesting clavarioid fungi from the hemiboreal zone of Finland. - Karstenia 48: 29-32. Helsinki. ISSN 0453-3402.

During a work in the provinces Åland (Alandia, Ahvenanmaa) and Varsinais-Suomi 24 species of clavarioid fungi (Basidiomycota) were collected, including the rare Multiclavula mucida, Ramaria fennica, Ramariopsis crocea, Typhula capitata, T. olivascens and T. spathulata. New to Finland are Typhula abietina and T. sphaeroidea. Most of the species are widely distributed in the hemiboreal zone in Europe. The localities, habitats, substrates and short ecological notes for the new and some rare species are given.
\end{abstract}

Key words: Distribution, Finland, hemiboreal, Typhula

Anton Shiryaev, Institute of Plant and Animal Ecology RAS, 8 March str. 202, 620144, Ekaterinburg, Russia; e-mail: 26081978@mail.ru

\section{Introduction}

The distribution and ecology as well as the species diversity of some fungal groups are poorly known, and the clavarioid fungi is one of those. The basic studies of this fungal group in Finland were those of Karsten $(1879,1881,1882,1899)$, but the distribution of most of the species could not be determined even 100 years later (Hansen \& Knudsen 1997). Since Hansen and Knudsen (1997) there is only one publication dealing with Typhula species. Shiryaev and Kotiranta (2007) made a check-list of the species in Finnish herbaria with some notes on the distribution, hosts and ecology.

The aim of this work is to describe the diversity and some ecological features of the clavarioid fungi in the hemiboreal zone in Finland.

\section{Material and methods}

A total of 52 specimens of clavarioid fungi were collected by the author in October 2007. In each locality a special effort was made to examine the main types of microhabitats. Specimens are deposited in the mycological herbarium of the Institute of Plant and Animal Ecology of Ural division of the Russian Academy of Sciences, Ekaterinburg (SVER). For the identification Corner (1950, 1970),
Berthier, (1976), Hansen and Knudsen (1997), Franchi and Marchetti (2001) were used, and the nomenclature follows http://www.indexfungorum.org/Names/Names. asp and that of vascular plants Hämet-Ahti et al. (1998). The biological provinces and collecting sites are according to Heikinheimo and Raatikainen (1981), and the provinces are illustrated in Hansen and Knudsen (1997: 28). The following abbreviations for substrates are used: Acer refers to $A$. platanoides, Betula to B. pendula and $B$. pubescens, Corylus to $C$. avellana, Fraxinus to $F$. excelsior, Picea to P. abies, Pinus to P. sylvestris, Populus to Populus tremula and Quercus to Q. robur,. Species new to Finland are marked with an asterisk $(*)$. The biologial province Alandia (Alland, Ahvenanmaa) is abbreviated as $\mathrm{A}$, and Varsinais-Suomi as V.

\section{List of species}

Multiclavula mucida (Pers.) R. H. Petersen Syn. Lentaria $m$. (Pers.) Corner

A: Lemland, Herrö $\left(59^{\circ} 55^{\prime} \mathrm{N}, 20^{\circ} 15^{\prime} \mathrm{E}\right)$, grassherb forest (Betula, Quercus, Corylus, Fraxinus, Picea, Viburnum opulus), on fallen trunk of Quercus, 2.X.2007 Shiryaev (SVER(F) 67435). V: Parainen $\left(60^{\circ} 17^{\prime} \mathrm{N}, 22^{\circ} 19^{\prime} \mathrm{E}\right)$, seashore with Alnus glutinosa and Populus, on decaying Populus trunk, 3.X.2007 Shiryaev (SVER(F) 67432). 
Lohja $\left(60^{\circ} 13^{\prime} \mathrm{N} 24^{\circ} 06^{\prime} \mathrm{E}\right)$, Tamminiemi Nature Reserve, luxuriant broad-leaved grass-herb forest, on Quercus trunk, 3.X.2007 Shiryaev (SVER(F) 67444).

Pterula gracilis (Desm. \& Berk.) Corner A: Jomala $\left(60^{\circ} 08^{\prime} \mathrm{N}, 20^{\circ} 01^{\prime} \mathrm{E}\right)$, partly cleared mixed forest (Picea, Pinus, Betula, Malus sylvestris, Acer, Sorbus aucuparia) near the sea shore, on decaying leaves of Betula, 1.X.2007 Shiryaev (SVER(F) 67437). V: Parainen $\left(60^{\circ} 17^{\prime} \mathrm{N}\right.$, $22^{\circ} 19^{\prime} \mathrm{E}$ ), luxuriant deciduous forest close to the seashore, on decaying leaves of Betula, 3.X.2007 Shiryaev (SVER(F) 67438).

Pterula multifida (Chevall.) Fr.

Syn. P. subulata Fr.

A: Jomala $\left(60^{\circ} 08^{\prime} \mathrm{N}, 20^{\circ} 01^{\prime} \mathrm{E}\right)$, grass-herb forest on foot-hill (Picea, Pinus, Betula, Malus sylvestris, Acer, Sorbus aucuparia) near the sea shore, on soil 1.X.2007 Shiryaev (SVER(F) 67416).

Ramaria fennica (P. Karst.) Ricken

A: Lemland, Herrö $\left(59^{\circ} 55^{\prime} \mathrm{N}, 20^{\circ} 15^{\prime} \mathrm{E}\right)$, grassherb forest (Betula, Quercus, Corylus, Fraxinus excelsior, Picea, Sorbus hybrida, Viburnum opulus), on soil, 2.X.2007 Shiryaev (SVER(F) 67423).

Ramariopsis crocea (Pers.) Corner

A: Lemland, Herrö $\left(59^{\circ} 55^{\prime} \mathrm{N}, 20^{\circ} 15^{\prime} \mathrm{E}\right)$, grassherb forest (Betula, Quercus, Corylus, Fraxinus, Picea, Sorbus hybrida, Taxus baccata, Viburnum opulus), on soil, 2.X.2007 Shiryaev (SVER(F) 67433).

*Typhula abietina (Fuckel) Corner A: Jomala $\left(60^{\circ} 08^{\prime} \mathrm{N}, 20^{\circ} 01^{\prime} \mathrm{E}\right)$, luxuriant grassherb forest on slope of foot-hill (Picea, Pinus, Alnus glutinosa, Betula, Sorbus aucuparia, Ribes alpinum) near the sea shore, on decaying Pinus needles, 1.X.2007 Shiryaev (SVER(F) 67428).

Typhula capitata (Pat.) Berthier

A: Lemland, Järsö $\left(60^{\circ} 01^{\prime} \mathrm{N}, 20^{\circ} 00^{\prime} \mathrm{E}\right)$, wet fern- and herb-rich luxuriant forest close to the seashore with Alnus glutinosa, Betula, Fraxinus, Hippophaë rhamnoides, Picea and Sorbus hybri$d a$, on decaying leaves of Calamagrostis arundinacea, 2.X.2007 Shiryaev (SVER(F) 67426).
Typhula caricina $\mathrm{P}$. Karst.

V: Parainen $\left(60^{\circ} 17^{\prime} \mathrm{N}, 22^{\circ} 19^{\prime} \mathrm{E}\right)$, seashore with Alnus glutinosa, on decaying leaves of Carex sp., 3.X.2007 Shiryaev (SVER(F) 67427).

Typhula lutescens Boud.

V: Parainen $\left(60^{\circ} 17^{\prime} \mathrm{N}, 2^{\circ} 19^{\prime} \mathrm{E}\right)$, luxuriant grass-herb forest on foot-hill of a steep north facing rock with Quercus, Tilia cordata, Betula, and Picea, on decaying Betula leaves buried in mosses, 3.X.2007 Shiryaev (SVER(F) 67434).

\section{Typhula olivascens Berthier}

V: Kaarina, Kakskerta $\left(60^{\circ} 22^{\prime} \mathrm{N}, 22^{\circ} 14^{\prime} \mathrm{E}\right)$, deciduous forest (Betula, Sorbus aucuparia, Acer, Picea), on decayed petioles of Dryopteris filixmas, 3.X.2007 Shiryaev (SVER(F) 67429).

\section{Typhula spathulata (Peck) Berthier}

A: Lemland, Järsö $\left(60^{\circ} 01^{\prime} \mathrm{N}, 20^{\circ} 00^{\prime} \mathrm{E}\right)$, grassherb forest close to the seashore (Betula, Corylus, Fraxinus, Picea, Viburnum opulus), on decaying twigs of Salix sp., 2.X.2007 Shiryaev (SVER(F) 67441). V: Kaarina, Kakskerta $\left(60^{\circ} 22^{\prime} \mathrm{N}, 22^{\circ} 14^{\prime} \mathrm{E}\right)$, cut forest area with bushes (Betula, Corylus, Sorbus aucuparia), on dead twig of Corylus, 3.X.2007 Shiryaev (SVER(F) 67430).

\section{*Typhula sphaeroidea Remsberg}

A: Lemland $\left(60^{\circ} 04^{\prime} \mathrm{N}, 20^{\circ} 10^{\prime} \mathrm{E}\right)$, deciduous grass-herb forest (Betula, Fraxinus), on decaying twigs of Fraxinus, 2.X.2007 Shiryaev (SVER(F) 67439). Jomala $\left(60^{\circ} 08^{\prime} \mathrm{N}, 20^{\circ} 01^{\prime} \mathrm{E}\right)$, pastured mixed grass-herb forest (Picea, Quercus, Pinus, Betula, Sorbus aucuparia) near the sea shore, on decayed twigs of Rubus sp., 1.X.2007 Shiryaev (SVER(F) 67440).

\section{Typhula struthiopteridis Corner}

A: Lemland, Järsö $\left(60^{\circ} 01^{\prime} \mathrm{N}, 20^{\circ} 00^{\prime} \mathrm{E}\right)$, fernand herb-rich luxuriant forest close to the seashore with Alnus glutinosa, Betula, Fraxinus, Hippophaë rhamnoides, Picea, Sorbus hybrida, on decaying petioles of Matteuccia struthiopteris, 2.X.2007 Shiryaev (SVER(F) 67424). V: Lohja, Tamminiemi Nature Reserve $\left(60^{\circ} 13^{\prime} \mathrm{N}\right.$, $\left.24^{\circ} 06^{\prime} \mathrm{E}\right)$, broad-leaved grass-herb forest, brook slope, on the decaying petioles of Matteuccia struthiopteris, 3.X.2007 Shiryaev (SVER(F) 67445). 
Typhula uncialis (Grev.) Berthier

A: Jomala $\left(60^{\circ} 08^{\prime} \mathrm{N}, 20^{\circ} 01^{\prime} \mathrm{E}\right)$, partly cut mixed forest (Picea, Pinus, Alnus glutinosa, Betula, Sorbus aucuparia) near the sea shore, on decayed Anthriscus sylvestris, 1.X.2007 Shiryaev (SVER(F) 67431). V: Kaarina, Kakskerta $\left(60^{\circ} 22^{\prime} \mathrm{N}, 22^{\circ} 14^{\prime} \mathrm{E}\right)$, deciduous forest with Betula, Corylus, Alnus glutinosa and Populus, close to a brook, on dead Petasites sp., 3.X.2007 Shiryaev (SVER(F) 67438).

\section{Discussion}

Altogether twenty-four species of clavarioid fungi were collected in the provinces Alland (Alandia) and Varsinais-Suomi (Regio aboënsis) including common species Clavulinopsis kunzei (Fr.) Corner, Ramaria gracilis (Pers. : Fr.) Quél., Typhula erythropus (Pers. : Fr.) Fr., T. graminum P. Karst., T. phacorrhiza (Reichard : Fr.) Fr., T. setipes (Grev.) Berthier, T. variabilis Riessi in Åland, and Clavaria fumosa Pers. : Fr., T. erythropus (Pers. : Fr.) Fr., T. phacorrhiza (Reichard : Fr.) Fr., T. quisquiliaris (Fr. : Fr.) Henn., T. setipes (Grev.) Berthier, T. variabilis Riess. in Varsinais-Suomi, as well as according recent studies (Shiryaev \& Kotiranta 2007) in Åland two new species for the country, viz. T. abietina (Fuckel) Corner and T. sphaeroidea Remsberg.

\section{Notes on some species}

Typhula abietina is an uncommon boreal species, known only in Eurasia with the ecological optimum in the southern boreal regions (Shiryaev 2004, 2007). It is widely but sparsely distributed from temperate zone to northern boreal areas, where it has been found on decaying needles of Abies alba, A. nordmanniana, A. sibirica, Picea abies, $P$. orientalis, Pinus sylvestris and $P$. sibirica. In boreal areas it grows from August to October in wet localities on decaying needles or leaves buried in mosses. In hemiboreal areas it fruits only in a short wet period in autumn in coniferous forests. In the temperate areas it is rare on dead needles on sandy soils or moist hill slopes, and the fruiting period is very short, from second part of October to November.

Typhula olivascens is a common boreal species, known only in Eurasia with the ecological optimum in the southern boreal and hemiboreal regions (Shiryaev 2004, 2007). It is widely distributed from temperate zone to middle boreal zone, where it has been found only on decaying petioles of Athyrium filix-femina and Dryopteris filix-mas. In the middle boreal zone it is rare and mostly mal-formed specimens are found close to brooks or lakes in early August. In southern boreal and hemiboreal zones it fruits from August to October in all kinds of localities with A. filixfemina or D. filix-mas. In temperate zone the species prefers northern shady wet slopes, where it is recorded in October-November and collected from Athyrium spp. and Dryopteris spp.

Typhula sphaeroidea seems to have a temperate distribution in Holarctic and is fairly common with ecological optimum in mixed- and broad-leaved forests (Shiryaev 2006, 2007). It is widely distributed from south taiga to subtropical zone but also on mountains up to the tree line and prefers decayed hardwood (Quercus, Fraxinus, Acer, Juglans, Pterocarya, Maakia, Sorbus, Cerasus) twigs as well as decaying herbs (Artemisia, Filipendula), bushes (Rosa, Rubus); rarely on Alnus and Betula, and not collected from coniferous debris. Fruiting period is short, in late autumn. In the hemiboreal zone it fruits in October, in temperate- and subtropical zones in October-November.

Typhula uncialis is one of the most common Typhula species in Holarctic, but, unexpectedly, rare in temperate- and hemiboreal zones, especially on areas close to the sea. During the fieldwork only two specimens were collected - for the first time in Åland (Shiryaev \& Kotiranta 2007).

Ramariopsis crocea and $R$. fennica grew in the same forest, but in different habitats: the first one on southern slope of a hill on calcareous soil and humus and with a rich herb- and shrub vegetation, whereas the second one was collected under canopy of hardwoods in more moist conditions on rich soil (mull) on northern slope of the hill. Short-living fruitbodies of Multiclavula mucida were collected twice on large, moist Populus trunk covered with algae, and once on moist Quercus in shaded forest.

Acknowledgement: I gratefully thank Dr. Heikki Kotiranta (Helsinki) for correction of the manuscript and for revising of the English. 


\section{References}

Hämet-Ahti, L., Suominen, J., Ulvinen, T. \& Uotila, P. (eds.) 1998: Retkeilykasvio. - Finnish Mus. Nat. Hist., Bot. Mus., Helsinki. 656 pp.

Hansen, L., Knudsen, H. (eds.) 1997: Nordic macromycetes 3 . Heterobasidioid, aphyllophoroid and gastromycetoid basidiomycetes. - Nordsvamp, Copenhagen. 444 pp.

Heikinheimo, O. \& Raatikainen, M. 1981: Paikan ilmoittaminen Suomesta talletetuissa biologisissa aineistoissa. - Ann. Entomol. Fennici 37(1): 1-27.

Karsten, P. A. 1879: Symbolae ad Mycologiam Fennicam 6. Basidiomycetes De B. - Medd. Soc. Fauna Flora Fennica 5: 15-46.

Karsten, P. A. 1881: Hymenomycetes Fennici. - Acta Soc. Fauna Flora Fennica 2(1): 1-40.
Karsten, P. A. 1882: Rysslands, Finlands och den skandinaviska halföns hattsvampar 2. Pip-, tagg-, hud-, klubb- och gelésvampar. - Bidrag Känned. Finlands Natur Folk 37(9): 1-257.

Karsten, P. A. 1899: Finlands basidsvampar. Floristiska handböcker för nybegynnare. - Soc. Fauna Flora Fennica, Helsingfors Centraltryckeri. Helsingfors. 186 pp, 9 pls.

Shiryaev, A. 2004: Clavarioid fungi of the Urals. I. The boreal zone. - Mikol. Fitopatol. 38 (4): 59-72.

Shiryaev, A. 2006: Clavarioid fungi of the Urals. - PhD thesis. Bot. Inst. RAS. St-Peterburg. 196 pp. [In Russian].

Shiryaev, A. 2007: Clavarioid fungi of the Urals. II. The nemoral zone. - Karstenia 47: 5-16.

Shiryaev, A. \& Kotiranta H. 2007: The genera Typhula and Pistillaria (Typhulaceae, Aphyllophorales) in Finland. A check-list of the species. - Karstenia 47: 49-54. 